\title{
Emociones y medios de comunicación. Una propuesta de análisis
}

\author{
Silvia Gutiérrez ${ }^{1}$ \\ Erick Vargas $^{2}$
}

\begin{abstract}
The purpose of this text is to present a methodological proposal for the study of emotions that are transmitted in the media, specifically in the press. The mass media disseminate emotions, and in some cases we could argue that their purpose is to arouse emotions in the people who consume them. It is therefore important to study how they appeal, reproduce and unfold emotions that concern a wide public. The methodological perspective has been designed following some of Frederick Ungerer's suggestions for the analysis of news stories and some methodological procedures that Christian Plantin has proposed for the analysis of the discursive dimension of emotions. In order to illustrate the proposal we have worked with a corpus of journalistic materials from two national newspapers, with different editorial alignments, on the enforced disappearance of 43 students from a Rural Teachers' College in Ayotzinapa, México, in September 2014.
\end{abstract} Keywords: emotions; mass media; written press; methodological proposal; Ayotzinapa.

Resumen: El propósito de este texto es presentar una propuesta de análisis para el estudio de las emociones que son trasmitidas en los medios de comunicación, particularmente en la prensa escrita. Los medios de comunicación propagan emociones, podríamos decir incluso que en algunos casos su objetivo es despertar emociones en las personas que los consumen. Es por tanto importante estudiar cómo estos medios, incitan, reproducen y difunden emociones en torno a problemáticas que atañen a un amplio público. La propuesta metodológica está construida a partir de algunos planteamientos de Friedrich Ungerer (1997) para el estudio de las emociones en los textos periodísticos, así como ciertos lineamientos metodológicos que Christian Plantin $(1998,2014)$ ha sugerido para el análisis discursivo de las emociones. Para ejemplificar dicha propuesta se ha trabajado con un corpus de notas y artículos periodísticos de dos periódicos nacionales de líneas editoriales distintas en relación con el caso de los 43 estudiantes desaparecidos de la Normal Rural de Ayotzinapa, México en septiembre de 2014.

Palabras clave: emociones; medios de comunicación; prensa escrita; propuesta de análisis; Ayotzinapa.

1 Universidad Autónoma Metropolitana, México.

2 Universidad Autónoma, Unidad Xochimilco. 
El estado emocional de una persona determina, en gran parte, la forma en que percibe el mundo y en esa percepción que tenemos del mundo los medios de comunicación juegan un papel fundamental. Los medios de comunicación propagan emociones, podríamos decir incluso que en algunos casos su objetivo es despertar emociones en las personas que los consumen. Es por tanto importante estudiar cómo estos medios con frecuencia relatan hechos dramáticos que se introducen en nuestro mundo de vida, transformando nuestra percepción de la cotidianidad. Tal es el caso de la desaparición de los 43 estudiantes de Ayotzinapa el cual hemos retomado para mostrar la importancia de estudiar las emociones a las que se apela en los materiales periodísticos.

Los medios de comunicación le dan a los acontecimientos una doble articulación. "Desde el punto de vista espacial, ponen en relación el espacio del acontecimiento con el espacio del espectador, y desde el punto de vista temporal, ponen en relación la historia pública con la memoria de las audiencias" (Fernández, 2010:13). Los temas, informaciones, narraciones, encuadres o fragmentos que se muestran en ellos, reordenan y dan coherencia al mundo que habitamos y describen/producen lo que se acepta, cómo se acepta y la forma de comunicarlo. Las emociones pueden influir en el grado de atención que se pone a determinada información, para su valoración, su selección o priorización y la posterior dirección que se dé al razonamiento basado en esa información.

Para abordar el estudio de las emociones en la prensa escrita consideramos importante primero señalar que si bien existen diferentes propuestas provenientes del análisis del discurso para analizar los medios de comunicación ( $c f$. Van Dijk, 1990; Charaudeau, 2003) y más específicamente la prensa escrita ( $c f$. Vasilachis, 1997; Fonte, 2002; Salgado, 2007; Zaslavsky, 2009; Gutiérrez, 2010a) no existen propuestas que incorporen de manera sistemática el análisis de la emoción en los diferentes materiales periodísticos, es por ello que consideramos importante sugerir un modelo analítico para estudiar las emociones que este medio de comunicación hace circular.

En el texto primero se presentan algunos planteamientos en relación con ciertas perspectivas que han abordado el análisis de las emociones y se especifica el enfoque adoptado en este estudio. Posteriormente se aborda la relación medios de comunicación y emociones, se resalta la importancia de su examen y se emiten algunos planteamientos en relación con la manera en que los medios pueden suscitar ciertas emociones en sus audiencias. De ahí se parte para presentar la propuesta metodológica y con el fin de ilustrar su aplicación se retoma un caso de estudio, el de la desaparición de los 43 estudiantes de la Normal Rural de Ayotzinapa México, se contextualiza brevemente el caso y se especifica el corpus de estudio. Para el análisis se retoma un acontecimiento específico de dicho caso y se cierra con algunas reflexiones finales sobre la importancia del estudio de las emociones en los medios de comunicación.

\section{El estudio de las emociones}

En el estudio de las emociones se pueden ubicar diferentes enfoques. Si bien hace unas tres décadas la mayor parte de la investigación realizada sobre las emociones provenía del campo de la psicología y la filosofía, actualmente existe un interés creciente en su estudio desde otras ciencias sociales como la sociología, la antropología, la lingüística, las neurociencias y otros 
campos de investigación. Es más actualmente se habla del giro afectivo en la ciencias sociales como un cambio en la producción de conocimiento que se basa en el estudio del afecto y la emoción.

Los enfoques existentes conciben a las emociones de manera distinta, se centran en problemáticas específicas y utilizan diferentes herramientas para su análisis. Si bien cada uno puede aportar diferentes maneras de abordar este objeto de estudio así como distintas categorías analíticas, en esta investigación hemos adoptado por una concepción que puede ser designada como un enfoque socio-discursivo.

Es un enfoque social ya que parte de la idea de que las emociones participan de un sistema de sentidos y valores que son propios de un conjunto social, es decir, considera a las emociones como experiencias construidas y compartidas socialmente. Al respecto la sociología de las emociones aporta planteamientos esenciales para entender su naturaleza, por ejemplo que las emociones están cargadas de significados, de sentidos anclados en contextos sociohistóricos específicos, en los que es necesario reconocer la dimensión normativa, la dimensión expresiva y la dimensión política (Hochschild, 1975) y también la necesidad de reconocer el vínculo sistemático entre las reacciones emocionales y la posición de un individuo en una jerarquía de estatus y poder (Kemper,1978).

En relación con la importancia del lenguaje para el estudio de las emociones ciertos planteamientos provenientes de la antropología de las emociones ayudan a comprender que estas no pueden ser cabalmente investigadas si no se atiende al lenguaje y el contexto específico en el que surgen y se intercambian. Además habría que señalar que "si las emociones son consideradas como fenómenos sociales, entonces el discurso es crucial para entender cómo son constituidas" (Lutz y Abu-Lughod, 1990:11). El estudio de las emociones a través del discurso, considerado como una práctica social, permite interpretar las emociones como algo que ocurre al interior de la vida social y que tiene efectos en esta realidad social. Lutz y Abu-Lughod señalan la necesidad de:

Establecer la fuerza pragmática del discurso emocional y el carácter social de la emoción mostrando cómo el centro de los discursos sobre la emoción (teorías locales acerca de las emociones) y los discursos emocionales (como despliegues emocionales de las formas lingüísticas) suelen ser las cuestiones sociales (Lutz y Abu-Lughod 1990: 13).

Además de estos aportes en relación con la caracterización e importancia del discurso emocional es necesario integrar trabajos que se inscriben en las teorías del discurso y la argumentación. Para ello incorporamos algunos planteamientos de investigadores clave en el campo del análisis del discurso. En primer lugar es necesario mencionar el trabajo pionero de Douglas Walton (1992), quien revalúa el papel de la emoción en la argumentación después de su exclusión como falacias ad pasiones en algunas de las propuestas modernas.

Las investigaciones de Christian Plantin (1998, 2014; Plantin y Gutiérrez, 2009), se constituyen actualmente en referencias obligadas en el campo de estudios de la emoción desde la perspectiva de la argumentación. Plantin parte del análisis argumentativo para proponer algunos planteamientos teóricos que se sistematizan y toman consistencia en un marco conceptual que tiene sus orígenes en la retórica clásica pero que, al mismo tiempo, necesita ser renovado y actualizado. Uno de los aportes centrales de los diferentes escritos de Plantin sobre el tema es el reconocimiento de "la inseparabilidad de la razón y la emoción" en un modelo descriptivo/explicativo de la argumentación basado en las nociones de interacción y desacuerdo entre oradores. 
Patrick Charaudeau (2000, 2012), también ha contribuido al estudio del despliegue de las emociones en el discurso político y más particularmente en el populista; una de sus principales contribuciones es que pone un énfasis particular en la especificación del punto de vista del análisis del discurso ante la problemática de las emociones, sobre todo en relación con las aproximaciones de la psicología social y la sociología.

Ruth Amossy $(2000,2010)$ se ha interesado en esclarecer cómo el sentimiento interviene en la interacciones argumentativas y en qué medida es compatible con la racionalidad; ha estudiado el discurso polémico el cual, a su parecer, se funda en un aparato argumentativo que modula en diferentes dosis lo racional y lo pasional, especialmente cuando el discurso interviene en una polémica difundida en el espacio público.

Las investigaciones de los autores mencionados tienen en común el hecho de remontarse a los orígenes del estudio de las emociones, principalmente a la obra de Aristóteles, y ubicar el análisis de las situaciones que pueden desencadenar un pathos determinado desde una perspectiva que parte del reconocimiento de la estrategia enunciativa, la situación social y sociocultural y el saber compartido.

El acercamiento discursivo a la exploración de las emociones tiene como objeto de estudio una serie de problemáticas específicas, por ejemplo: su naturaleza como una actividad significante; las diferentes maneras de expresarlas o comunicarlas; su reconstrucción a partir de indicios emocionales específicos y de reglas precisas; la orientación emocional de un discurso. No se trata de decir qué es la ira o la calma, sino de ver cómo se construye un discurso susceptible de enojar o de calmar (cf. Plantin, 2014 [2011]). Si bien el análisis discursivo de las emociones se focaliza en la dimensión discursiva es importante señalar que este acercamiento tiene que ser complementado con aportes que provienen de otros campos disciplinares, como los que ya hemos mencionado.

\section{Medios de comunicación y emociones}

La perspectiva teórica para el estudio de las emociones que hemos delimitado permite indagar sobre las emociones que son transmitidas por los medios de comunicación ya que se centra en los medios lingüístico-argumentativos que pueden orientar la inferencia emocional en contextos sociohistóricos específicos.

La comunicación mediática juega cada vez más un papel determinante en la manera en que se construye el sentido de la realidad social y se difunde. Desde luego, lo que transmiten los medios no tiene un carácter absoluto, pero su discurso tiene la capacidad de impactar en el público. Los medios, entre otros procesos, desempeñan algún papel en nuestras formas de percibir el entorno, de delimitar nuestras actuaciones y de proporcionar marcos de interpretación de los acontecimientos.

Los media pueden ser concebidos como marcos de interpretación ya que por su carácter masivo, facilitan la construcción de consensos sociales, "legitiman ciertas explicaciones de los comportamientos y señalan cómo deben interpretarse los temas informativos a través de un orden metafórico que genera la construcción de los campos semánticos para la interpretación" (Ceballos, 2008: 272).

Dado que los medios de comunicación suscitan, despiertan emociones, es necesario estudiar en qué medida los medios nos inducen a tener determinadas experiencias emotivas. Experiencias que son construidas socialmente, es decir, son dotadas de significado por la sociedad y compartidas intersubjetivamente por los sujetos sociales en sus interacciones cotidianas. 
Para Paul Virilio (2007) los medios amplifican y modelan las experiencias subjetivas e inciden en la construcción de consensos y emociones al sincronizar los estados afectivos como respuesta a la demanda social de sentido. Al estudiar el manejo que hacen los medios de comunicación del riesgo y la incertidumbre Gil Calvo (2003) se pregunta si el miedo colectivo se funda en una base real o es producto de una percepción subjetiva, o si más bien es incentivado por los medios de comunicación, es decir, por la presión que ejercen las informaciones y discursos de dichos medios en el imaginario colectivo.

Un discurso mediático puede dar lugar a distintas interpretaciones, a partir de las coyunturas y características del público al que se dirige, pero dicho discurso también es susceptible de producir distintas emociones o la misma emoción con intensidad variable en cada persona.

El tratamiento de las emociones en los medios tiene el poder de congregar las diferentes subjetividades de los ciudadanos en torno a ciertos temas que resultan fundamentales para una vida pública viable en términos de respeto de opiniones diferentes y deliberación sobre materias de interés público.

\section{Prensa escrita y emociones}

La labor de los periodistas es, en cierta manera, paradójica. Por un lado, sus discursos deben ser lo más apegados a los hechos, por lo que existe una tendencia a una especie de precisión del lenguaje cuando se habla o se escribe sobre un tema con una carga afectiva compleja, esto dependiendo del tipo de diario del que se trate y de la naturaleza de sus contribuciones. Por otro lado, en sus prácticas cotidianas terminan por darse cuenta de que las emociones intervienen, a veces de manera inconsciente, en lo que escriben o dicen.

Un medio como la prensa escrita participa activamente en la gestión de las emociones del público al que se dirige. Por lo general, en la prensa se percibe un factor de fuerte activación afectiva. Para Bonhomme y Horack (2010:71) incluso los periódicos más serios "no escapan a la movilización de los afectos en el desarrollo de sus comentarios a fondo sobre la actualidad, ya sea en sus editoriales o en sus reportajes".

De acuerdo con Ungerer (1997), los textos periodísticos generalmente no son incluidos en los géneros emocionales; sin embargo, como señala el autor:

[...] no hay duda de que los artículos periodísticos tienen un impacto en el lector. Aún los textos que son superficialmente no-emotivos como los reportes de las finanzas, las guías de programación, los resultados del futbol o los reportes del clima pueden despertar emociones fuertes en lectores individuales" (1997:307).

Bohomme y Horak (2010), señalan que la prensa escrita destinada a priori a la transmisión de información, es un medio que, deliberadamente o no, ejerce una doble influencia psicológica sobre sus lectores:

Por un lado, despierta los afectos mediante sus títulos-choque y su predilección por los acontecimientos susceptibles de alterar la opinión; por otro, suscita -en particular a través de diferentes figuras sociodiscursivas entre ellas la del eufemismo - un efecto narcótico que difumina las emociones públicas, especialmente en los dominios político y administrativo (Bohomme y Horak, 2010: 71).

La prensa, así como los noticiarios de la radio o de la televisión, se asemejan mucho más a rituales de duelo y de horror, con una altísima carga emocional, que a un proceso 


\section{Conexão Letras}

de mera transmisión objetiva de informaciones, o a un ágora pública en la que los ciudadanos deciden razonando el destino de su comunidad (Bericat, 2005).

\section{El acercamiento metodológico}

Si bien existen diferentes propuestas para el análisis de la construcción discursiva de las emociones, que provienen del campo del análisis del discurso, entre ellas las que ya hemos mencionado, en este estudio nos interesa proponer un acercamiento que permita captar y reconstruir la manera en que en la prensa escrita, en sus diferentes materiales periodísticos, difunde, propaga y desencadena ciertas emociones en sus lectores. Para ello hemos articulado una propuesta de análisis a partir de algunos planteamientos de Friedrich Ungerer (1997) para el análisis de las emociones en los textos periodísticos desarrollados en su texto "Emotions and emotional language in English and German news stories", así como ciertos lineamientos metodológicos para el estudio de la emoción en el discurso que propone Christian Plantin (1998, 2014; Plantin y Gutiérrez, 2009).

Primero explicamos los planteamientos de Ungerer. Su propuesta de análisis parte del sistema de inferencia que parece ser responsable del impacto emocional y tiene como propósito el examen de los medios lingüísticos que desencadenan las inferencias emocionales en los textos periodísticos. Para describir el trasfondo comunicativo de las noticias se apoya en el conocido modelo de Bühler (1934) del signo lingüístico.

Diagrama 1. Modelo de Ungerer la emoción y el marco pragmático de las noticias

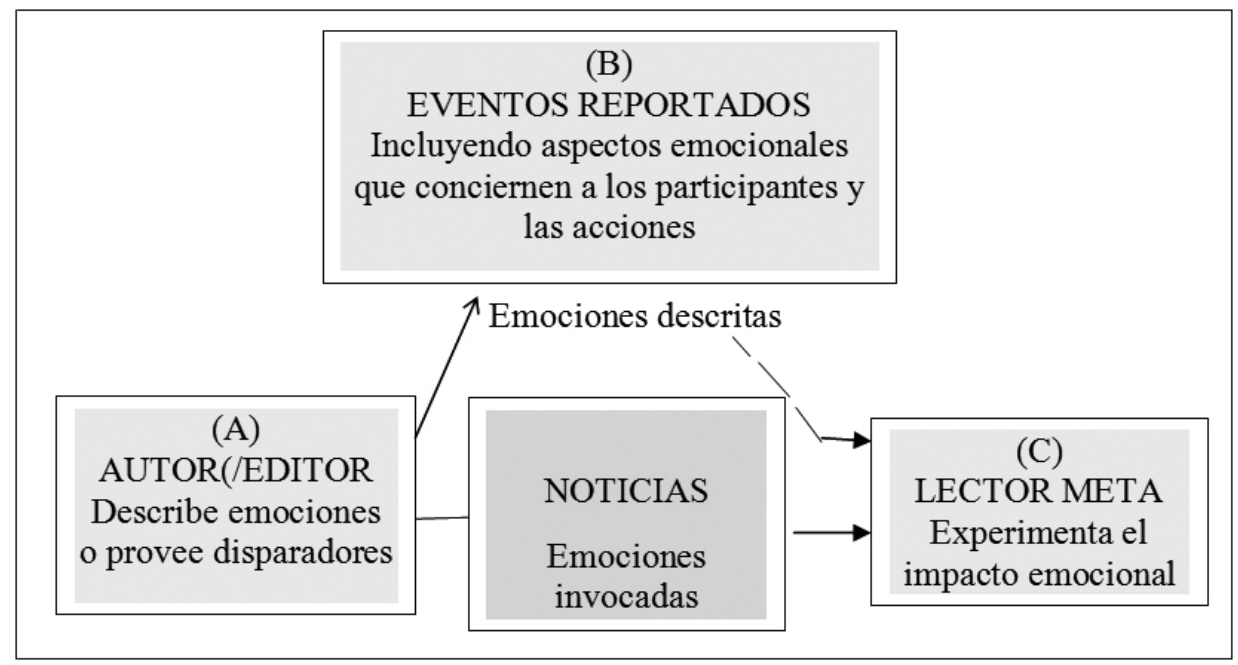

Fuente, Ungerer (1997: 308) basado en el modelo de Bühler

En el diagrama el destinador (A) es representado por el autor/editor para dar cuenta del fenómeno de múltiple autoría que es típica de los textos periodísticos. El ítem central, el signo en el modelo de Bühler, es remplazado por el de las noticas. En el componente referencial de Bühler "los objetos y relaciones" son vistos como los eventos reportados (B), finamente el destinatario (C) es representado como el lector meta quien es quien experimenta el impacto emocional. 
El principio de análisis se sustenta en el sistema de inferencias que es, probablemente, el responsable del impacto emocional en el lector. Este principio de inferencia se relaciona con la noción de implicatura de Grice (1975). Grice se propuso explicar el porqué de la existencia del significado implícito en la comunicación humana; para tales fines, formuló el principio de cooperación, que describe los aspectos sociales que conllevan el buen funcionamiento del intercambio lingüístico, de tal forma que la comunicación se lleve a cabo de manera satisfactoria. Se centró en el estudio de los principios que condicionan la interpretación de los enunciados, más específicamente en identificar y caracterizar los mecanismos que regulan el intercambio comunicativo y el significado añadido, es decir, sobre lo que no está dicho pero que, sin embargo, se quiere comunicar. Dicho principio se basa en cuatro normas que Grice denomina máximas: cantidad, calidad, relación y manera (Grice, 1975: 516-517).

En el caso de la prensa escrita estas máximas pueden corresponder a los lineamientos prácticos que los periodistas deben de seguir y que están asociados con el newworthiness o valores de noticiabilidad. Ungerer se basa en esos valores o criterios y en lo que denomina dimensiones emocionales para proponer el siguiente esquema (véase cuadro1). En la columna de la izquierda se incluyen los procesos encargados de la inferencia emocional y las estrategias o máximas, y en la de la derecha se desglosan los disparadores lingüísticos utilizados para provocar la reacción emocional que se pretende.

\section{Cuadro 1. Principios de inferencia emocional, estrategias y disparadores lingüísticos}

\begin{tabular}{|l|l|}
\hline \multicolumn{1}{|c|}{ Principios y estrategias } & \multicolumn{1}{|c|}{ Disparadores lingüísticos } \\
\hline I Principios de relevancia emocional & Ítems deícticos, términos de \\
1. Principio de proximidad (nosotros VS ellos) & parentesco, formas cariñosas de \\
- Concéntrate en lo que es cercano al lector. & dirigirse a alguien. \\
2. Principio de animacidad ("vida y muerte") & Vocabulario del desastre o la \\
- Concéntrate en lo que pone en peligro la vida o lo que & calamidad: asesinato, violación, \\
genera vida para los humanos. & asalto, temblor, bajas, víctimas, \\
3. Principio de rango y número. & heridos. \\
-Concéntrate en lo que concierne a mucha gente que es & Numerales y otras expresiones de \\
importante. & cantidad, títulos \\
\hline II Principios de procesamiento & Adjetivos evaluativos, ítems lexi- \\
4. Principio de evaluación emocional & cales con connotaciones negati- \\
-Provee evaluaciones basadas en las normas cultura- & vas/positivas; \\
les (evaluación negativa y/o positiva; evaluaciones más & ítems que disparan el proceso de \\
específicas) & evaluación: utilización de detalles \\
5. Principio de intensidad de la presentación & vívidos y enlaces metafóricos \\
-Se drástico. & con dominios emocionalmente \\
6. Principio del contenido emocional & establecidos (la Biblia); \\
-Menciona aspectos emocionales de eventos de manera & términos emocionales descripti- \\
explícita. & vos como adjetivos, sustantivos y \\
& verbos. \\
\hline \multicolumn{2}{|c|}{ Fuente: Ungerer (1997: 314º } \\
\end{tabular}

Como ya habíamos mencionado, el principio de inferencia depende de las conexiones que pueden producir los interlocutores del acto de comunicación y esas inferencias dependen, a

3 La traducción es nuestra del original en inglés. 
su vez, del conocimiento que esos interlocutores pueden tener de la situación de enunciación.

Para armar la propuesta analítica también nos hemos apoyado en algunas reflexiones y procedimientos metodológicos que Christian Plantin (cf. 1998, 2014; Plantin y Gutiérrez, 2009) ha planteado para el estudio las emociones desde una dimensión discursiva. El modelo que sugiere tiene como fin la reconstrucción de las emociones y la reconstitución de los recorridos emocionales de los interactuantes o actores que aparecen en el texto. Se aplica tanto a los textos escritos como a las interacciones contempladas bajo sus aspectos multimodales.

En el análisis se combina la localización directa de las emociones (enunciados de emoción) y su localización indirecta, a partir de los indicios situacionales y los indicios de expresión. La expresión directa de las emociones se hace por medio de los enunciados de emoción (EE). Un EE afirma o niega que un actor ("experenciante") se encuentra en tal o cual estado psicológico. En términos lingüísticos, un EE une un lugar psicológico a un término de emoción ("estaba furiosa "). También puede incluir la fuente de la emoción ("esto me enfurece"). Los términos de emoción pueden ser definidos o catalogados.

En otros casos, las emociones no son designadas, es decir, ningún término de emoción explícito está presente en el discurso; sin embargo, el material verbal puede contener indicaciones que permiten la reconstrucción de la derivación de una emoción a partir de la descripción de estados fisiológicos emocionales o de ciertas acciones típicas. La expresión indirecta de las emociones (emoción implicada) se hace por dos vías. Por una parte, al reportar "señales posteriores" de la emoción, es decir, modos de comportamiento característicos de una persona emocionada (manifestaciones fisiológicas, mimo-posturo-gestuales o de conducta). Por otra parte, por "señales anteriores", inductores estereotipados que restituyen la situación bajo un formato narrativo-descriptivo que induce tal o cual clase de emociones (cfr. Plantin y Gutiérrez, 2009).

Otro nivel de análisis en la investigación de la dimensión emocional de un texto es identificar a los experenciantes ${ }^{4}$, tanto concretos como potenciales, para identificar qué emoción es atribuida a quién. Recordando los elementos básicos del proceso comunicativo podríamos apuntar que hay las emociones del enunciador y las emociones del enunciatario.

Para el estudio de la emoción también es necesario precisar los principios (o topoi) que aseguran la coherencia del "discurso conmovido". La idea es explotar todos los indicios indirectos de las emociones para reconstruir las emociones, es específico los topoi que permiten identificar quién hizo qué, cuándo, dónde, cómo, por qué, etc.

Otro de los temas en los que últimamente ha trabajado Plantin es el de los términos de emoción y los términos de orientación emocional. Para él la descripción de una emoción puede no contener ningún término de emoción y al mismo tiempo permitir inferencias a una emoción, en este caso lo que propone ir creando un la sub-diccionario, a partir de sus derivados lexicales o familia morfo-léxica semánticamente homogénea que puede ser utilizado para mostrar que el número de las "palabras de emoción" va mucho más allá de las pequeñas decenas que se consideran habitualmente, y que sus relaciones bien atestiguadas con la emoción son detalladamente diferenciadas y pueden ser inventariadas. Tales datos de referencia son imprescindibles para el análisis del discurso emocionado (cf. Plantin 2016).

Además de estos planteamientos incorporamos las reglas de producción retórica de la emoción que Plantin (basado en Lausberg, 1960) propone para identificar los principios generadores de la emoción. Estas reglas pueden ser consideradas como descriptivas: "si quiere emocionar a su público, ¡haga esto!” pero también como prescriptivas: "esto emociona a la gente" (Plantin, 2014: 185).

4 Si bien en algunos de sus textos en español Plantin utiliza el término experimentador, últimamente prefiere usar el de experenciante porque da más la idea de la persona que experimenta o siente la emoción. 
Cuadro 2. Reglas de producción retórica de la emoción

\begin{tabular}{|l|l|}
\hline \multicolumn{1}{|c|}{ Regla } & Medio lingüístico asociado (figura) \\
\hline $\begin{array}{l}\text { 1. Estimule la emoción } \\
\text {-por medio de objetos emocionantes } \\
\text {-por medio de imágenes de acontecimientos emo- } \\
\text { cionantes }\end{array}$ & \\
\hline $\begin{array}{l}\text { 2. Represente las situaciones- estímulos } \\
\text {-describa los hechos emocionantes } \\
\text {-amplifique los hechos emocionantes } \\
\text {-dramatice los hechos indiferentes } \\
\text {-categorice: encuentre analogías }\end{array}$ & $\begin{array}{l}\text { Evidencia } \\
\text { Amplificación, repetición (expolitio) } \\
\text { similitud }\end{array}$ \\
\hline $\begin{array}{l}\text { 3. } \text { Muestre la emoción } \\
\text {-muestre personas emocionadas } \\
\text {-muéstrese emocionado (ethos) } \\
\text {-identifíquese: hable como las personas emocionadas }\end{array}$ & Repetición \\
\hline 4. Salga del formato & Metábasis \\
\hline
\end{tabular}

Fuente: Plantin, 2014:189-190

En el siguiente diagrama incluimos un modelo de análisis que puede ser de utilidad para analizar la manera en que la prensa escrita aborda las emociones en sus materiales periodísticos (Véase Diagrama 2).

Diagrama 2 .Modelo analítico para el estudio de la emoción en textos periodísticos

\begin{tabular}{|c|c|}
\hline CONDICION & $\begin{array}{c}\text { S DE PRODUCCIÓN DEL DISCURSO } \\
\qquad \\
\text { po de material periodístico } \\
\downarrow \\
\text { e organizan el discurso emotivo } \\
\downarrow\end{array}$ \\
\hline Topoi & Principios y reglas \\
\hline ¿Qué? Tipo de acontecimiento & $\begin{array}{l}\text { Preconstructos eufóricos o disfóricos. Principio de Anima- } \\
\text { cidad: vida / muerte }\end{array}$ \\
\hline ¿Quiénes? Tipos de personas & $\begin{array}{l}\text { Principio de rango: tipo de personas y de proximidad (no- } \\
\text { sotros/ellos). Regla estimule la emoción: personas emocio- } \\
\text { nadas, imágenes personas conmovidas }\end{array}$ \\
\hline ¿Cómo? Intensidad & $\begin{array}{l}\text { Principio de intensidad de la presentación: analogías, } \\
\text { metáforas. Regla: Represente las situaciones -estímulos: } \\
\text { descripción, amplificación, dramatización }\end{array}$ \\
\hline ¿Dónde? Lugar & $\begin{array}{l}\text { Principio de proximidad. Emocionalmente marcado o en } \\
\text { relación con personas determinadas }\end{array}$ \\
\hline ¿Cuántos? Cantidad & Principio de número: número de personas involucradas \\
\hline ¿Por qué? Causa/agente & $\begin{array}{l}\text { Principio de evaluación emocional: actitud ante el aconte- } \\
\text { cimiento }\end{array}$ \\
\hline
\end{tabular}

Fuente: elaboración propia 
En este esquema hemos articulado la propuesta de Ungerer con la de Plantin con el fin de proponer algunos de los ejes de análisis que consideramos importantes para poder identificar, dependiendo del tipo de material periodístico, los mecanismos o disparadores lingüístico-argumentativos que permiten formatear una situación o acontecimiento no solo como emocionante, sino orientada hacia uno u otro tipo de emoción específica.

Como en todo análisis es necesario primero reconstruir las condiciones de producción del discurso para ubicar los actores, instituciones, y hechos, es decir, el entorno material e institucional del discurso. También se tiene que determinar la naturaleza del tipo de material periodístico del que se trate; por ejemplo en las portadas intervienen otros dispositivos que funcionan más en el nivel visual, por ejemplo la jerarquización de la información, las fotografías, tamaño de los titulares y subtítulos. Posteriormente, se procedería a identificar los disparadores lingüístico-argumentativos generadores de la emoción de forma directa o indirecta, es decir, si la emoción ésta explícitamente expresada o si más bien hay que inferirla por medio de los indicios situacionales y de los términos de orientación emocional La pregunta retórica que introduce cada uno de los topoi sirve de ayuda para orientar la identificación de la información y establecer el vínculo entre el evento y las emociones. Finalmente de lo que se trata es de identificar a qué emociones se apela, y de qué manera, para poder determinar la orientación emocional del texto.

\section{Estudio de caso: la desaparición de los 43 estudiantes de Ayotzinapa}

Para ilustrar la aplicación de la propuesta metodológica hemos seleccionado un caso de estudio que hemos venido trabajando (cf. Vargas, 2017, Gutiérrez, 2017), el de la desaparición de los 43 estudiantes de Ayotzinapa.

Existen acontecimientos que quedan grabados en la memoria colectiva, y seguramente ahí permanecerán por algún tiempo, esto puede depender del impacto emocional que tuvo en las personas, y en la sociedad en su conjunto, dicho suceso. La desaparición de los 43 normalistas de Ayotzinapa en septiembre del 2014 fue un acontecimiento que cimbró tanto la opinión pública nacional como internacional; éste ocupó por varios meses las portadas, los editoriales, notas informativas y artículos de opinión de diarios tanto nacionales como internacionales, razón por la cual lo hemos retomado como caso de estudio.

Durante la noche del 26 al 27 de septiembre del 2014, estudiantes de la Normal Rural Raúl Isidro Burgos de Ayotzinapa fueron atacados por policías municipales de Iguala y Cocula. Murieron seis personas, entre ellas tres estudiantes, 25 resultaron heridas y 43 fueron detenidas y posteriormente entregadas, según testimonios, a integrantes del grupo delictivo Guerreros Unidos, una escisión del cártel de los Beltrán Leyva (México). Hasta la fecha, la versión oficial es que el alcalde de Iguala, José Luis Abarca, ordenó a la policía municipal detenerlos al suponer que se dirigían a boicotear el acto de informe de gobierno de su esposa, María de los Ángeles Pineda, titular del Sistema Nacional de Desarrollo Integral de la Familia (DIF) municipal.

El conocimiento de los hechos conmocionó a la opinión pública mexicana, sobre todo, al hacerse evidente la negligencia de las autoridades locales y federales y su incapacidad para dar con el paradero de los 43 estudiantes. Ante esta situación, los familiares de los desaparecidos y otros estudiantes iniciaron la búsqueda intensificando el operativo al descubrirse una serie de fosas clandestinas en dos zonas cercanas a Iguala (4 octubre, 2014).

El ataque de los agentes públicos contra los normalistas y la actuación de las autoridades ante el caso desataron críticas de numerosas organizaciones civiles tales como Amnistía Internacional, Human Rights Watch, y Centros de Derechos Humanos mexicanos, esto sirvió de presión para que el gobierno federal actuara. 
El 4 de octubre de 2014 la Procuraduría General de la República (PGR) asume la responsabilidad de investigar el caso de la desaparición de los jóvenes gobierno de Guerrero y envía "un grupo de investigadores y agentes del Ministerio Público Federal" a Guerrero para encabezar las pesquisas. Once días después de la desaparición de los jóvenes (6 de octubre) el presidente Enrique Peña Nieto habla por primera vez sobre Ayotzinapa. El 7 de noviembre de 2014, más de cuarenta días después de los hechos, el Procurador General, Jesús Murillo Karam ofrece una conferencia de prensa sobre los hechos en la que señala que el presidente municipal de Iguala había dado la orden de "contener" a los estudiantes y que los habían llevado al basurero de Cocula donde fueron asesinados y calcinados, versión que los familiares y estudiantes de la Normal Rural de Ayotzinapa rechazaron unánimemente.

Son varias las versiones que han surgido sobre los hechos: la llamada "verdad histórica" (la oficial) y la del Grupo Interdisciplinario de Expertos Independientes (GIEI) de la Comisión Interamericana de Derechos Humanos (CIDH), pero habiendo transcurrido ya más de tres años aún no se sabe con exactitud ni los motivos y responsables de la desaparición, ni el paradero de los estudiantes.

\section{Corpus de estudio}

Para conformar el corpus de estudio hemos considerado algunos criterios que tienen que ver con la naturaleza interna y externa de los textos periodísticos y hemos buscado que exista una cierta homogeneidad pero a la vez también cierta heterogeneidad que permita la comparación. Para ello hemos retomado dos criterios que Eliseo Verón (1971) utilizó en un estudio de prensa escrita: 1) "las diferencias sociológicamente significativas entre las fuentes", en este caso se buscó que fueran dos diarios de mexicanos de líneas ideológicas diferentes: La Jornada ${ }^{5}$ y El Universal ${ }^{6}$ y 2) "la respuesta de dichas fuentes a un estímulo común: un cierto hecho social al que ambas se refieren en los contendidos de sus mensajes" (Verón, 1971:148), en este estudio hemos retomado ciertos sucesos en relación con la desaparición de los 43 normalistas, que tuvieron un importante impacto en la comunidad nacional e internacional. Los acontecimientos seleccionados fueron los siguientes: los primeros días del acontecimiento, la aparición de fosas en el estado de Guerrero, las primeras manifestaciones de apoyo a los padres, la declaración del ex procurador de la república Jesús Murillo Karam sobre la "verdad histórica", las Acciones Globales por Ayotzinapa, el informe del Grupo Interdisciplinario de Expertos Independiente y finalmente, el cumplimiento de un año del acontecimiento.

Otro criterio que también se tomó en cuenta es el de la heterogeneidad discursiva; se procuró que el corpus estuviera constituido por diferentes tipos de materiales periodísticos, tomando esto en cuenta se eligieron las primeras planas, los editoriales, los artículos de opinión y las columnas.

Además de estos criterios, que tienen que ver más con la naturaleza del discurso periodístico, otro de naturaleza interna fue que en los materiales seleccionados se pudiera identificar o reconstruir las emociones a las que se apelaba.

5 El diario La Jornada fue fundado en septiembre de 1984 por Carlos Payán, tuvo sus orígenes en un grupo de periodistas que por limitaciones a la libertad de prensa dejaron el proyecto del diario UnomasUno. Durante muchos años se ha caracterizado por sus críticas y denuncias de los grupos en el poder, el apoyo a las causas populares y la homogeneidad de su línea editorial. $C f$. http://www.jornada.unam.mx/2010/09/19/edito

6 El Universal es uno de los diarios de mayor circulación en México, fue fundado por el legislador constituyente, Félix F. Palavicini en 1916. Se presenta como un periódico de centro, más cercano a la clase política y, aunque crítico con los excesos de los poderes públicos, tiende a ser contemporizador de las instituciones con independencia del partido político que esté en el poder. Cf. Zepeda, 2005. 


\section{Presentación de los resultados del análisis}

Para la ilustrar la propuesta analítica hemos retomado uno de los acontecimientos ya mencionados, el de la Cuarta Acción Global por Ayotzinapa (20 noviembre de 2014) ya que marcó un hito importante en el desarrollo de las protestas por la desaparición de los 43 normalistas; de todas las protestas anteriores, esta fue una de las más contestatarias y concurridas desde que comenzó el movimiento, por ello, tanto medios de comunicación nacionales como internacionales le brindaron una importante cobertura en sus principales espacios informativos. Otra razón es que en estos materiales periodísticos fue posible identificar situaciones o términos emocionales que eran posibles de reconstruir por medio de la propuesta de análisis aquí presentada.

Condiciones de producción del discurso. Cuando acontece la 4ta acción global por Aytozinapa (20 de noviembre, 2014) el país atravesaba por una profunda crisis de legitimidad del gobierno que se veía agravada por ciertos acontecimientos. Uno de ellos fue la adquisición de una residencia valuada en más de 80 millones de pesos, por la pareja presidencial Peña-Rivera mediante Grupo Higa, empresa perteneciente a Juan Armando Hinojosa Cantú, uno de los mayores contratistas del gobierno federal. La periodista Carmen Aristegui en su noticiero radiofónico y en su portal web reveló el posible conflicto de intereses entre el Presidente Enrique Peña Nieto y dicho empresario. La crisis que se desató se debió no sólo al supuesto conflicto de intereses entre las partes, sino también por la procedencia de los recursos para saldar un inmueble de ese valor, abonó al clima de irritación, por la corrupción e impunidad que ya permeaba en gran parte del país.

Otro suceso fue el hallazgo de diversas fosas clandestinas en Iguala. El primer descubrimiento de restos humanos se hizo el 4 de octubre del 2014. Posteriormente, el 10 de octubre se anuncia también que otras cuatro fosas clandestinas habían sido encontradas cerca de Iguala, Guerrero. De igual manera, es importante señalar que en el recorrido que hicieron los padres de los normalistas por diferentes entidades del país, se dieron a conocer otros casos de desapariciones forzadas y se descubrieron más fosas clandestinas.

Todos estos hechos explican, en buena medida porque, durante la marcha de la 4ta Acción Global, el tema de las fosas clandestinas ocupara un lugar central en el discurso de los padres y madres de los normalistas. Declaraciones que pocos medios nacionales retomaron.

En la movilización que se llevó a cabo en la Ciudad de México, participaron estudiantes, campesinos, trabajadores, académicos, artistas, organizaciones sociales, sindicatos, grupos de derechos humanos, grupos religiosos, familias, jóvenes, y normalista de distintas partes del país. Se trató de una movilización multitudinaria y conformada por distintos sectores sociales. El acontecimiento tuvo resonancia a nivel internacional en países de Europa, Estados Unidos y en América Latina; diversos estudiantes manifestaron su apoyo al colocar veladoras en universidades, y mostrar en avenidas de las capitales las fotografías de los normalistas.

A pesar de que la mayoría de los manifestantes se condujeron de manera pacífica, al término de ésta un grupo de personas con el rostro cubierto causó disturbios, ya que arrojaron diversos objetos, algunos de ellos explosivos, contra los cuerpos policiacos. Este hecho desencadenó un enfrentamiento, entre la policía antimotines y este grupo que derivó en el desalojo del Zócalo y con el arresto de 31 personas. Esta forma de proceder de las autoridades fue cuestionada por organizaciones civiles, de derechos humanos y por ciertos sectores de la sociedad.

Para presentar el análisis hemos diseñado unos cuadros para anotar los enunciados/argumentos así como los disparadores lingüístico-argumentativos de la emoción; cada cua- 
dro ha sido diseñado dependiendo de la naturaleza del material que se analiza, es decir, dependiendo del objetivo del informador en el marco de la situación de discurso que le pertenece, o el género que ha seleccionado. Primero se expone el análisis de las portadas de los diarios y una breve interpretación, posteriormente se analizan los dos editoriales.

\section{Análisis 1. Portada La Jornada, 20 de noviembre, 2014}

Iniciamos el análisis con el estudio de las primeras planas ya que éstas constituyen el material donde se jerarquiza la información que se presenta al público, es decir se resaltan las noticias que consideran más importantes. En este material periodístico nos interesa analizar, en primer lugar, cómo está jerarquizada la información y en segundo la información que contienen los titulares o encabezados, partiendo de la idea de que estos son "la expresión del más alto nivel de la macro estructura informativa" (Van Dijk, 1990: 83). Siguiendo a Van Dijk, se trata de un resumen de lo expresado en el cuerpo de la noticia, que se posiciona en el primer nivel informativo y por esa razón, es lo primero que los lectores leen de la información. Los demás elementos de las portadas: balazos o llamados a notas y subtítulos también constituyen motivo de análisis, primero se identifican los ejes de análisis y luego se describen e interpretan. Dado que los aspectos no verbales también son de suma importancia, hemos incluido, de manera general, el análisis de las imágenes de las portadas de los diarios.

Cuadro 4. Portada, La Jornada, 21 de noviembre 2014.7

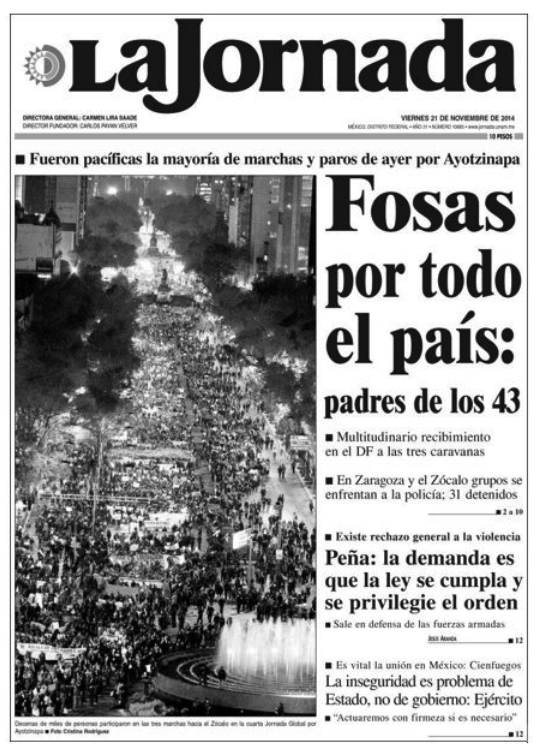

\begin{tabular}{|l|l|}
\hline \multicolumn{2}{|c|}{ LA JORNADA } \\
\hline \multicolumn{1}{|c|}{ ENUNCIADOS } & \multicolumn{1}{c|}{ PRINCIPOS/REGLAS } \\
\hline $\begin{array}{l}\text { Titular: Fosas por todo el país: } \\
\text { padres de los 43 }\end{array}$ & $\begin{array}{l}\text { Animacidad: Términos que designan } \\
\text { situaciones de/muerte/ /horror/ dolor/ } \\
\text { sufrimiento/pena/ } \\
\text { Proximidad: padres de los 43 }\end{array}$ \\
\hline $\begin{array}{l}\text { Fotografia: Plano general largo } \\
\text { que muestra una gran multitud, } \\
\text { capta la participación ciudadana } \\
\text { en la cuarta Jornada Global en el } \\
\text { D.F. }\end{array}$ & $\begin{array}{l}\text { R1. Estimule la emoción: por medio de } \\
\text { imágenes emocionantes. } \\
\text { /participación /apoyo/ aliento/ }\end{array}$ \\
\hline $\begin{array}{l}\text { Balazo: } \text { Multitudinario } \\
\text { recibimiento en el DF a las tres } \\
\text { caravanas }\end{array}$ & $\begin{array}{l}\text { Rango y Número: Multitudinario } \\
\text { remite a la cantidad de participantes a } \\
\text { partir de dicho término se puede inferir } \\
\text { situaciones emocionantes como: } \\
\text { /solidaridad/apoyo/calidez/afecto/ }\end{array}$ \\
\hline $\begin{array}{l}\text { Balazo: En Zaragoza y el Zócalo } \\
\text { grupos se enfrentan a la policía; } \\
\text { 3l detenidos }\end{array}$ & $\begin{array}{l}\text { Animacidad: Términos que designan } \\
\text { episodios violentos: /hostilidad/ } \\
\text { ataques/heridos/ } \\
\text { Rango y Número: 31 detenidos }\end{array}$ \\
\hline $\begin{array}{l}\text { Antetítulo: Fueron pacíficas la } \\
\text { mayoría de marchas y paros de } \\
\text { ayer por Ayotzinapa }\end{array}$ & $\begin{array}{l}\text { Evaluación Emocional: "pacificas" } \\
\text { designa una situación positiva en } \\
\text { relación con las marchas. }\end{array}$ \\
\hline $\begin{array}{l}\text { Balazo: Existe rechazo general a violencia } \\
\text { avaluación Emocional: "violencia" } \\
\text { término de emoción que designa una } \\
\text { situación negativa. }\end{array}$ \\
\hline
\end{tabular}

http://www.jornada.unam.mx/2014/11/21/

En primer lugar, cabe señalar que en relación con el eje ¿qué? es decir, de qué hecho emocionante se habla, la portada de la edición de este día estuvo dedicada por completo a la manifestación de la Cuarta Acción; tanto la fotografía como el titular dan cuenta de

7 (N. ed.) Publicação autorizada pelo editor de imagens do Periódico aos autores do artigo. 
la dimensión del evento. Una primera cuestión que, consideramos necesario señalar, es que el tamaño del titular sobresale del resto de los demás elementos de la portada. En este sentido, a partir del enunciado: Fosas por todo el país: padres de los 43, identificamos elementos de carácter emocional que tienen que ver con el principio de animacidad, ya que el término fosas hace referencia a situaciones que ponen en peligro la vida. Dicho principio tiene que ver con la alusión a contextos de /fatalidad/, /brutalidad/ y / desastres/. Además, la denuncia de la existencia de fosas por todo el país, no lo hace el gobierno, o alguna asociación civil, sino los propios padres de los 43 normalistas. Es por ello que a partir de estos elementos se puede inferir que la intención emocional del titular es despertar emociones asociadas con el /horror/ y la /indignación/ ${ }^{8}$. Por otro lado, la aseveración de que hay fosas por todo el país dota al enunciado de un significado de / agravio/ o /calamidad/, pues no se trata sólo de Iguala o del estado de Guerrero, sino de una gran parte del territorio nacional.

En la parte inferior del titular aparecen dos balazos. El primero de ellos destaca: multitudinario recibimiento de la ciudad a las tres caravanas; el segundo: En Zaragoza y el Zócalo grupos se enfrentan a policías: 31 detenidos. En cuanto al primer balazo, ubicamos la intensidad de la presentación, ya que el término multitudinario, hace referencia algo que concierne a mucha gente. En este sentido, el "multitudinario recibimiento" tiene que ver con la manifestación de /solidaridad/ de buena parte de la sociedad (principalmente la capitalina) hacia el movimiento de los 43 .

En relación con el antetítulo este define, en buena medida, el enfoque y tratamiento que el diario otorgó a las manifestaciones. En él se subraya: Fueron pacíficas la mayoría de las marchas y paros de ayer por Ayotzinapa, si recuperamos sólo el fragmento: Fueron pacíficas identificamos el principio de evaluación emocional ya que provee una evaluación basada en las normas de la cultura, que presupone que no siempre las manifestaciones son pacíficas.

En lo que concierne a la fotografía, esta se sitúa en la parte izquierda y ocupa poco más de la mitad de la primera plana. Se trata por razones de ubicación y espacio del segundo elemento más importante de la portada. Ahí ubicamos la regla "estimula la emoción" ya que prescribe que se muestren imágenes emocionantes. Un aspecto que convierte a esta fotografía en una imagen emocionante es el encuadre utilizado para tomarla, un plano general largo en picada, utilizado para mostrar un gran escenario o multitud, en este caso la avenida Paseo de la Reforma ocupada por miles de manifestantes (30 mil según datos oficiales) de la Cuarta Acción Global. En términos generales, consideramos que esta imagen puede despertar emociones relacionadas con la /solidaridad/, en específico, con los padres de los desaparecidos.

\section{Cuadro 5. Portada, El Universal, 21 de noviembre 2014.9}

En cuanto a la portada de El Universal también observamos que el titular sobresale de los demás elementos, ya que tanto el tamaño de su tipografía como su ubicación, situado del lado izquierdo de la portada, le confieren relevancia. En relación con el tipo de acontecimiento, es decir, de qué se trata el evento emotivo, en el titular de la portada se habla de la marcha y se resalta el carácter violento de ésta; en la selección del titular se puede

8 Para precisar claramente el estatuto reconstruido de las emociones o los términos de orientación emocional inferidos, éstos se anotarán entre barras oblicuas.

9 (N. ed.) Publicação autorizada pelo Periódico aos autores do artigo. 
identificar principio de evaluación emocional: "manchan violentos" al expresar una valoración específica en torno a la protesta por los 43. A partir de lo anterior inferimos que el titular puede detonar emociones relacionadas con situaciones de /caos/, /agresividad/, ya que implica un balance negativo de la marcha.

Dos balazos se ubican en la parte inferior del titular, éstos coadyuvan a reforzar esa manera de designar el acontecimiento, especialmente el primero, donde se informa: "detienen a 31 por agresiones". El principio que identificamos es el de animacidad ya que a partir de la palabra agresiones es posible inferir que se descaderaron situaciones de / enfrentamientos/, /provocaciones/y /ataques/.

El segundo elemento textual que sobresale, es el subtítulo. En el enunciado: "Los tres poderes cierran filas por seguridad y paz", ubicamos el principio de rango y número, ya que remite no solamente a un poder sino a los tres y porque en términos de rango refiere a los actores políticos que encarnan los tres poderes de la unión: el Ejecutivo, el Legislativo y el Judicial. Dar peso a las declaraciones de los representantes de estos tres poderes indica que los reconoce como fuentes con alta credibilidad. Esto se ve reforzado con el hecho de presentar las fotografías de cada uno de ellos.

Cabe mencionar que algunos de los términos que se retoman en el subtítulo como: "seguridad" y "paz", son los mismos términos que enuncian los actores políticos para argumentar su rechazo a la "violencia". Esto evidencia cierta reproducción de los mensajes oficiales al incluir citas o frases muy específicas de los políticos. Pero es notable que el diario en su portada no incluya ningún mensaje o alusión a los manifestantes o a los padres de los desaparecidos.

Finalmente, el tercer elemento a destacar es la fotografía que se ubica en la parte central de la página. Aunque en esta portada comparte espacio con otras imágenes, su tamaño y ubicación la posicionan como un elemento importante que da cuenta de la importancia del acontecimiento. La fotografía es muy similar a la que aparece en la portada de La Jornada; sin embargo, no comunica la misma intensidad emocional al ser más pequeña que en el otro diario y al no ser la única que aparece.

\section{Interpretación de las portadas}

Cabe señalar que en el diseño de las portadas, todo responde a una intencionalidad: el tamaño de la tipografía, la colocación de una nota, su contigüidad con otras, las palabras con que se resumen las declaraciones de uno u otro de los actores principales, la selección y tratamiento que se da a una fotografía, su acompañamiento o no de un pie de foto. El panorama de elementos de interpretación se amplía al considerar a cada elemento como parte de un contexto (la plana en cuestión).

En relación con el análisis de las dos primeras planas de los diarios es importante señalar que en ambos existen diferencias significativas en cuanto al tratamiento, jerarquización del contenido y tratamiento de las emociones. Por ejemplo, podemos mencionar, que no sólo existe un posicionamiento distinto en torno a la Cuarta Jornada, sino que se observaron tratamientos, en cierta manera, disimiles.

Si se observan los titulares, en el caso de La Jornada su interés se centra en llamar la atención sobre el panorama de muerte que asola al país; apelando al descubrimiento de fosas como parte del contexto de caos. Por otro lado, para El Universal lo relevante son los hechos violentos que acontecieron al finalizar la marcha. De esta manera, ambos 


\section{Conexão Letras}

diarios en sus portadas remiten a la violencia y el caos como elementos consustanciales del conflicto; sin embargo, la diferencia radica en que las circunstancias y los actores que lo detonan son distintos en cada medio. Por ejemplo, la fuente de la "violencia" para La Jornada la constituye fundamentalmente el narcotráfico y la delincuencia organizada (quienes provocan que haya fosas clandestinas) mientras que para El Universal al enunciar su titular como "Manchan violentos..." son el pequeño grupo de encapuchados que se enfrentaron con las autoridades los detonantes de la violencia.

En relación con la orientación emocional, la portada de La Jornada puede despertar emociones asociadas con el /horror/, la / barbarie/ e incluso la /indignación/ debido al conjunto de elementos que expone en su primera plana, particularmente en su titular que denuncia la existencia de fosas en todo el país. ¿Quién no se sentiría indignado al enterarse de la existencia de fosas clandestinas de seres desaparecidos por todo el país? Cabe señalar que para Nussbaum (2006) en la indignación hay desde odio, rabia o resentimiento por algo que aconteció, y se supone produjo un daño. Así, el daño a terceros es fundamental para distinguir lo indignante de otro tipo de emociones. En este caso el daño a otros es evidente en lo que se enuncia y, por tanto, se puede inferir que es dicha emoción la que se puede suscitar. Además, la indignación "es una emoción que resulta de la empatía con los que sufren y de la evaluación de las razones de ese sufrimiento" (Cadena-Roa, 2002: 81), al sentirse indignados por los acontecimientos se provoca también / empatía/ con los padres. En cambio, en la portada de El Universal, es posible reconstruir situaciones que tiene que ver con escenarios de /enfrentamientos/ y /agresiones/, contrastando notoriamente con las valoraciones positivas que hace La Jornada en torno a que la mayoría de las marchas transcurrieron de manera pacífica.

Por otro lado, a partir de la información que proporciona El Universal, en su recuadro y subtítulo, se pueden reconstruir dos valoraciones distintas; una donde se promueve la idea de contextos violentos que ubicamos en el titular y otra donde los tres poderes apelan al "orden y la paz"30. Esto implica que, en una misma portada, se difundieron dos posiciones argumentativo-emocionales opuestas, que se pueden sinterizar en: paz vs violencia. Donde es posible deducir que la serenidad y la paz provienen de las instituciones del estado y las manifestaciones de desastre y violencia de la ciudadanía que protesta.

De igual manera, en cuanto al tratamiento que en sus portadas dieron los dos diarios al acontecimiento, existe una relación de oposición en relación con la valoración que hacen de la marcha. Por ejemplo, en La Jornada es posible leer en sus titulares la voz de los padres, mientras que en El Universal no aparece algún comentario o alusión a sus demandas.

\section{Análisis de los editoriales}

El estudio de los editoriales es de suma importancia ya que éstos expresan el posicionamiento del diario ante el acontecimiento que consideran de mayor importancia para el día de la edición y porque el modo de organización del discurso que predomina es el argumentativo. Para registrar las emociones a las que se apela en los editoriales hemos utilizado un esquema parecido al anterior.

Antes de iniciar con el análisis, es importante señalar que algunos de los argumentos seleccionados es posible reconstruir varios disparadores lingüístico -argumentativos; sin embargo nos centramos en la identificación de los recursos que consideramos más relevantes. Comenzamos el análisis con el editorial de La Jornada. 
Cuadro 6. Editorial "Arbitrariedad y criminalización de la protesta", La Jornada, 23 de noviembre 2014

\begin{tabular}{|l|l|}
\hline \multicolumn{1}{|c|}{ Argumentos } & \multicolumn{1}{|c|}{ Disparadores } \\
\hline $\begin{array}{l}\text { Titular: Arbitrariedad y criminalización de la } \\
\text { protesta }\end{array}$ & $\begin{array}{l}\text { ¿Qué? la protesta. } \\
\text { Evaluación emocional: califica el tipo } \\
\text { de acciones }\end{array}$ \\
\hline $\begin{array}{l}\text { - Entre los consignados, acusados de delitos } \\
\text { como homicidio en grado de tentativa, asociación } \\
\text { delictuosa y motín, se encuentran estudiantes y } \\
\text { activistas. }\end{array}$ & $\begin{array}{l}\text { ¿Quiénes? Los acusados. } \\
\text { Animacidad: Términos que designan } \\
\text { situaciones emocionales negativas: ho- } \\
\text { micidio, asociación delictuosa, motín }\end{array}$ \\
\hline $\begin{array}{l}\text {-Las detenciones arbitrarias y sin fundamento se } \\
\text { traducen en una vulneración de la legalidad }\end{array}$ & $\begin{array}{l}\text { ¿Cómo? Intensidad } \\
\text { Evaluación emocional: Términos que } \\
\text { remiten a situaciones emocionales } \\
\text { negativas: detenciones arbitrarias, sin } \\
\text { fundamento, vulneración de la legali- } \\
\text { dad, descontento, condenable } \\
\text { Analogía: similitud tan condenable... } \\
\text { policial reiterado contra ciudadanos inocentes, } \\
\text { incapacidad de las fuerzas del orden para distin- } \\
\text { guir entre inocentes y presuntos culpables. } \\
\text { como }\end{array}$ \\
\hline $\begin{array}{l}\text {-Un trato jurídico equiparable al de asesinos, } \\
\text { narcotraficantes y secuestradores, y que sean } \\
\text { enviados a penales federales con una velocidad } \\
\text { inusual. }\end{array}$ & $\begin{array}{l}\text { ¿Cómo? Intensidad } \\
\text { Analogía: similitud con el trato que se } \\
\text { da a los asesinos, narcotraficantes y } \\
\text { secuestradores. }\end{array}$ \\
\hline $\begin{array}{l}\text { El gobierno federal ha ensayado intentos discur- } \\
\text { sivos por justificar el uso excesivo de la fuerza } \\
\text { y por criminalizar las protestas sociales en un } \\
\text { momento en que la suma de indignaciones que } \\
\text { recorren el país parecen haberse articulado en } \\
\text { torno al reclamo de la búsqueda y presenta- } \\
\text { ción de los 43 normalistas. }\end{array}$ & $\begin{array}{l}\text { ¿Por qué? agentes: el gobierno federal } \\
\text { ¿Contenido emsidad } \\
\text { La indignación como un actor: recorre } \\
\text { el país }\end{array}$ \\
\hline
\end{tabular}

http://www.jornada.unam.mx/2014/11/23/index.php?section=edito

Cabe destacar que en relación con los marcadores de orientación emocional, es decir, los pahtemas, en específico el topoi ¿Qué? que remite a los contenidos emotivos del evento, el editorial se centra en dos aspectos; el primero de ellos, que hubo un uso excesivo de la fuerza por parte de las autoridades contra los manifestantes, el segundo que las personas detenidas durante la protesta fueron personas "inocentes", víctimas de la arbitrariedad de los cuerpos policiacos federales y capitalinos. A partir de estos dos tópicos el diario desarrolla su postura.

En el argumento: "Entre los consignados, acusados de delitos como homicidio en grado de tentativa, asociación delictuosa y motín", observamos que los términos "homicidio", "asociación delictuosa" y "motín" tiene que ver con el principio de animacidad, ya que constituyen situaciones que ponen en peligro la vida o que puede generar vida para los humanos. No obstante, en relación con el encuadre emocional del texto, este tipo de términos emocionales aunque están ligados al campo del $/ \mathrm{miedo} /$ por la gravedad de los delitos, en este caso más bien pueden evocar sentimientos de /indignación/ y /coraje/ porque las acusaciones no concuerdan con la dimensión del conflicto; además de que a los se inculpa son estudiantes, como agente receptor de la criminalización del Estado 
hacia este sector. Al respecto, el diario señala: se les dio un trato jurídico equiparable al de asesinos, narcotraficantes y secuestradores.

Por otro lado, en el argumento: "Las detenciones arbitrarias y sin fundamento se traducen en una vulneración de la legalidad lo que [...] multiplica el descontento, de por sí vasto, que recorre el país...", localizamos el principio de evaluación emocional, ya que términos como "vulneración" o "arbitrarias" pueden ser susceptibles de evocar sentimientos de carácter negativo, asociados al /enojo/, la /repulsión/, la /injusticia/ que el lector puede experimentar en torno a la forma en que las autoridades procedieron.

Posteriormente, en el argumento: "Por lo demás, tan condenable como el atropello policial reiterado contra ciudadanos inocentes, la incapacidad de las fuerzas del orden para distinguir entre inocentes y presuntos culpables", localizamos nuevamente una evaluación que por medio de una analogía transfiere la condena al atropello de ciudadanos inocentes a la incapacidad de la policía para distinguir entre inocentes y culpables. Las emociones que podemos reconstruir a partir de dicha evaluación tienen que ver un sentimiento de /vulnerabilidad/ que experimenta la sociedad frente a las fuerzas del orden. En este sentido, para Theodor Kemper (2001), la forma en que los actores perciben la "inferioridad" o la "superioridad" tiene que ver con el rol de estatus y poder que cada actor desempeña. Su teoría establece que existe una relación entre las reacciones emocionales y la posición de un individuo en la jerarquía social, lo que puede tener consecuencias para la acción política.

Al respecto cabe señalar, por ejemplo, que los “ciudadanos inocentes" están desprovistos de poder, y por ende pueden experimentar un sentimiento de indefensión frente a las autoridades, mientras que, las autoridades pueden ser percibidas como abusivas y represoras. Esta relación de superioridad/inferioridad al ser asimétrica puede detonar sentimientos de /rabia/, /indignación/ e /indignación/ en el lector.

En el enunciado: [...] "el gobierno federal ha ensayado intentos discursivos por justificar el uso excesivo de la fuerza y por criminalizar... las sumas de indignaciones recorren el país" ubicamos el principio de contenido emocional, dado que a partir de una prosopopeya, que consiste en atribuir a los seres inanimados o abstractos características y cualidades propias de los seres animados, las "indignaciones" recorren el país. Pero también, es importante resaltar que la "suma de las indignaciones" hace referencia a un sentimiento acumulado por múltiples agravios y violaciones, no sólo por el caso Ayotzinapa.

Por último, es necesario mencionar que los argumentos aquí analizados guardan relación con la lógica argumentativa-emocional de la portada, ya que frases como: "detenciones arbitrarias", "vulneración de la legalidad", "violencia" y "uso excesivo de la fuerza" forman parte del constructo emocional que difunde La Jornada.

Cuadro 7. Editorial, “Respuesta al clamor social”. El Universal, 21 de noviembre 2014

\begin{tabular}{|l|l|}
\hline Argumentos & Principios/disparadores \\
\hline Titular: Respuesta al clamor social & $\begin{array}{l}\text { ¿Qué? la respuesta de la ciudadanía } \\
\text { Intensidad de la presentación. } \\
\text { Detalles vívidos: clamor social }\end{array}$ \\
\hline $\begin{array}{l}\text {-El Estado [...] deben tomar consciencia del tamaño del } \\
\text { clamor social. }\end{array}$ & $\begin{array}{l}\text { ¿Por qué? agente: El Estado } \\
\text { ¿Cómo? Intensidad } \\
\text { Evaluación emocional: }\end{array}$ \\
$\begin{array}{l}\text {-son muchas autoridades, muchos civiles silenciosos y va- } \\
\text { rias instituciones corrompidas las que hicieron posible que } \\
\text { existiera un gobierno municipal al servicio del crimen. }\end{array}$ & $\begin{array}{l}\text {-Términos que designan situaciones } \\
\text { emocionantes: clamor y agentes institu- } \\
\text { ciones corrompidas, civiles silenciosos }\end{array}$ \\
\hline
\end{tabular}


-es ahora cuando millones de personas esperan, de todos los que conforman el Estado, una reacción tan grande como la tragedia que la generó.

¿Durante cuántos sexenios creció el cáncer siendo que pudo ser atacado cuando apenas se desarrollaba?

Los autores materiales e intelectuales del secuestro existían, así de brutales como son ahora, desde hace años.

El florecimiento de protestas de tantas personas en tantos lugares no puede obedecer sólo a la indignación frente a un solo acto, por terrible que éste sea.

Es más bien, y justamente por la crueldad que lo sucedido en Iguala entrañó la gota que derramó el vaso de la tolerancia...
¿Cuántos? Cantidad

Principio de número: millones de personas

¿Cómo? Analogía: reacción tan

grande como la tragedia que la generó

¿Cómo? Intensidad: Lazos meta-

fóricos: creció el cáncer...

-Detalles vívidos: secuestro, brutales

Analogía: la brutalidad de ahora con la de antes

¿Cómo? Intensidad

Contenido emocional: Términos emocionales explícitos: indignación Términos que se relacionan con situaciones emocionales negativas: terrible, crueldad

Metáfora: la gota que derramó el vaso de la tolerancia

http:/www.eluniversalmas.com.mx/editoriales/2014/11/73424.php

En primer lugar queremos señalar que este editorial contrasta notoriamente con la portada del diario, ya que a diferencia de esta última, algunos de los elementos que se subrayan tienen que ver con los niveles de violencia y corrupción que el gobierno toleró durante años y responsabiliza tanto a la clase política como a la sociedad por los hechos acontecidos en Iguala. El eje de su desarrollo, como el título del editorial indica, gira en torno al clamor social que exige un alto a la corrupción gubernamental. A continuación, analizamos algunos de los fragmentos más significativos.

En el argumento: "El Estado [...] deben tomar consciencia del tamaño del clamor social" ubicamos el principio de evaluación emocional ya que prescribe lo que el Estado debe hacer. En este caso el término "clamor" refiere a situaciones relacionadas con el /descontento/, la /indignación/ y el nivel de /enojo/ de la sociedad. De igual manera, en el enunciado: "son muchas autoridades, muchos civiles silenciosos y varias instituciones corrompidas las que hicieron posible que existiera un gobierno municipal al servicio del crimen", observamos otra evaluación emocional, en este caso sobre el papel que jugaron ciertos actores de la sociedad "civiles silenciosos" como el de instituciones corrompidas.

Cuando el diario argumenta: "[...] millones de personas esperan, de todos los que conforman el Estado, una reacción tan grande como la tragedia que la generó." se puede identificar tanto el principio de rango y número al expresar la cantidad de personas que demandan resultados a las autoridades, así como una analogía ya que el tamaño de la respuesta debería ser tan grande como la tragedia que la generó. En este sentido, vale la pena destacar que si bien al inicio de las protestas para exigir resultados participaban principalmente los padres de los desaparecidos, y algunos normalistas, y ciertos sectores sociales que generalmente participan en las protestas, en el momento en el que es publicado este editorial las protestas ya había alcanzado dimensiones nacionales e internacionales. 
Párrafos más abajo El Universal plantea: “¿Durante cuántos sexenios creció el cáncer siendo que pudo ser atacado cuando apenas se desarrollaba?" en este interrogante ubicamos la intensidad de la presentación de la emoción ya que se utiliza una metáfora por medio de la cual se asocia la degradación sistemática del gobierno con un mal médico, como lo es el cáncer.

El principio de intensidad de la presentación, lo ubicamos en el siguiente enunciado: "Los autores materiales e intelectuales del secuestro existían, así de brutales como son ahora, desde hace años", el adjetivo "brutales" expresa de forma dramática las prácticas que ejercen los criminales y también ahí ubicamos un argumento de analogía entre la naturaleza de los secuestradores de ahora y de antes. Asimismo, la descripción de crímenes como el secuestro o los asesinatos puede llevar al lector a asociarlos con contextos de /violencia/ y /barbarie/ que predominan en buena parte del territorio nacional.

Finalmente, en el argumento: "El florecimiento de protestas de tantas personas en tantos lugares no puede obedecer sólo a la indignación frente a un solo acto, por terrible que éste sea", localizamos el principio de contenido emocional que, como su máxima lo indica, tiene que ver con expresar emociones de manera explícita, en este caso es la /indignación/. Pero además adquiere relevancia porque, según el diario, se trata de una emoción que se ha ido acumulando y que comparten muchas personas de diversos lugares.

Cabe señalar que este editorial, pone el acento no sólo en las protestas, sino también en las causas que las originaron, por ello es posible señalar que la /indignación/ a la que continuamente hace alusión forma parte del cúmulo de atropellos y actos terribles cometidos a lo largo de los años y no sólo a un hecho aislado. El siguiente argumento expresado por medio de una metáfora ejemplifica lo anterior: "Es más bien, y justamente por la crueldad que lo sucedido en Iguala entrañó, la gota que derramó el vaso de la tolerancia".

\section{Interpretación general}

En relación con la dimensión emocional, identificamos que la /indignación/, la /violencia/ y la /rabia/ aparecen reiteradamente de forma explícita en ambos editoriales; no obstante, es importante resaltar que se tratan de construcciones argumentativo-emocionales distintas que tienen que ser relacionadas con el contexto en que aparecen para identificar, de manera más precisa, el tratamiento y la posición que los diarios adoptaron.

Por ejemplo, mediante la reconstrucción de los enunciados fue posible ubicar términos y situaciones en las que los agravios y las injusticas constituyen formas diferenciadas de expresar el /enojo/ o el /horror/ ante determinados hechos. La denuncia principal que hace La Jornada, y que puede ser fuente de enojo, son los abusos de autoridad hacia la ciudadanía, pero para El Universal, el eje principal, y posible detonador de indignación, es el nivel de corrupción gubernamental. También, observamos que los editoriales en distintos puntos describen términos que pueden evocar emociones de carácter negativo. Expresiones como "atropellos", "tragedia", "violencia", "cáncer" o "represión" disparan procesos evaluativos que a su vez pueden producir impactos emocionales relacionados con la /ira/, la /rabia/, la /indignación/ etc.

En este sentido, en el editorial de La Jornada observamos que la "represión" los "abusos de autoridad" y la "criminalización de la protesta" constituyen aspectos preponderantes en su contenido, no así en el caso de El Universal, dado que se enfoca más bien 
en expresar tres aspectos: el incremento del descontento social, las responsabilidades compartidas que derivaron en la masacre (poniendo al mismos nivel de responsabilidad a las autoridades y a la sociedad), y finalmente, la invitación que hace el diario a "retomar la confianza en la clase política".

Vale la pena mencionar que tanto El Universal como La Jornada emitieron juicios en torno a lo acontecido en la marcha; no obstante, El Universal apela de manera más directa al lector en torno a lo que debería hacer y reflexionar sobre el conflicto (como si se tratara de un juez con autoridad moral). En cambio, en La Jornada, observamos duras críticas al gobierno y un respaldo general a las acciones de la sociedad, particularmente, a los manifestantes que fueron arrestados.

Ambos editoriales recurrieron al uso de palabras choque como "brutales", "terrible", "crueldad" que pueden disparar emociones relacionadas a la /desesperanza/, el /miedo/ o la /angustia/. Pero al mismo tiempo sobresalen emociones relacionadas con la /indignación/ y el /clamor/ ambas, insumos importantes para el mantenimiento de los ciclos de la protesta social.

\section{Reflexiones finales}

Desde nuestro punto de vista, el análisis de las emociones en la prensa escrita es de utilidad ya que permite hacer visible que aunque los diarios se presenten como fuentes objetivas, en el uso de las palabras, la jerarquización de la información, las fotografías seleccionadas se apela de una u otra forma a las emociones que pretenden despertar en sus lectores, tal es el caso del acontecimiento de Ayotzinapa que hemos analizado.

La evaluación emocional es uno de los tipos de los procedimientos argumentativos que más aparece en todo discurso argumentativo-emocional y por tanto es necesario identificarlo ya que por medio de ellos se puede detectar la posición del hablante. Al realizar evaluaciones basadas en normas y principios de la cultura es más fácil provocar un efecto pathemico en el lector.

La emoción vinculada con un acontecimiento que afecta a una persona varía según la posición de este acontecimiento en el sistema de valores de la persona en que se pretende despertar la emoción. Esto nos lleva a considerar que la orientación emocional de un término emocional puede cambiar, incluso invertirse, en función de su contexto y de su situación de empleo.

Dado que las emociones no se experimentan de manera mecánica, sino que forman parte de procesos complejos que se van articulando según cada individuo, cultura, sociedad, contexto social, etc., es importante resaltar que la emoción experimentada, no dependerá sólo del hecho en sí mismo, sino también de la atribución causal que realice el sujeto, pero para saber cuál fue dicha atribución se requiere de un estudio de recepción que pueda confirmar el tipo de emociones experimentadas.

Para finalizar consideramos necesario señalar que el estudio de la emoción nunca es sencillo porque las emociones forman parte de un proceso vivo y pueden sufrir múltiples y enigmáticas transmutaciones, voluntarias e involuntarias, conscientes e inconscientes. La vergüenza se puede convertir en rabia, la alegría en llanto o el dolor en placer (cfr. Bericat, 2012). La inferencia depende de las conexiones que pueden producir los interlocutores del acto de comunicación y esas inferencias dependen, a su vez, del conocimiento que esos interlocutores pueden tener de la situación de enunciación. 
AMOSSY, R. Le pathos ou le rôle des émotions dans l'argumentation . En : L'argumentation dans le discours. Paris: Nathan, 2000.

. La indignación frente a las "stock-options" de la Societé Générale. Emoción y argumentación en: el discurso polémico. Versión. Estudios de Comunicación y Política, México: UAM, Xochimilco, n. 24, 2010, p.17- 40.

BERICAT, E. La cultura del horror en las sociedades avanzadas: de la sociedad centrípeta a la sociedad centrífuga. REIS, Revista Española de Investigaciones Sociológicas, n. 110, 2005. Disponible en: <http://www.redalyc.org/articulo. oa?id=99715250002> [Fecha de consulta: 10 de abril de 2016].

. Emociones. En: Sociopedia. España: Universidad de Sevilla, 2012, p.1-13. BONHOMME, M; HORAK, A. La desdramatización de las emociones en la prensa escrita. El eufemismo político-administrativo. Versión. Estudios de Comunicación y Política, México: UAM Xochimilco, n 24, 2010, p. 71-91.

CADENA-ROA, J. Strategic Framing, Emotions, and Superbarrio-Mexico City's Masked Crusader. Mobilization. An International Quarterly n. 7, 2002, p. 201-216. CEBALLOS, M. Las emotividades sociales y los medios de comunicación.

Pensamiento y Cultura, v. 11, n. 2, diciembre, 2008, p. 263-275.

CHARAUDEAU, P. Problématisation discursive de l'émotion. En: PLANTIN, C. DOURY, M. ; TRAVERSO, V. (Éd.). Les émotions dans les interactions. Lyon : Presses Universitaires de Lyon, 2000, p. 125-155.

El discurso de la información. La construcción del espejo social. Gedisa:

España, 2003.

. Las emociones como efectos de discurso. Revista Versión. Estudios de Comunicación y Política, México: UAM, Xochimilco, n. 26, 2012, p. 97-118.

ENCISO DOMÍNGUEZ, Giazú y LARA, Alí. "Emociones y ciencias sociales en el s. XX: La precuela del giro afectivo". Athenea Digital, 14(1), 2014, pp. 263-288. http:// dx.doi.org/10.5565/rev/athenead/v14n1.1094

FERNÁNDEZ PEDEMONTE, Damián. Conmoción pública: los casos mediáticos y sus públicos. Buenos Aires: La Crujía Ediciones, 2010.

FONTE, I. La nación cubana y Estados Unidos. Un estudio del discurso periodístico. México: COLMEX-UAM, 2002.

GIL CALVO, E. El miedo es el mensaje. Riesgo, incertidumbre y medios de comunicación. Madrid: Alianza, 2003.

GRICE, H. P. Logic and Conversation. En: COLE, P.; MORGAN, J. L. Syntax and semantics 3: Speech Acts. Nueva York: Academic Press, 1975, p. 41-58.

GUTIÉRREZ, S. Discurso periodístico: una propuesta de análisis En: Comunicación y

Sociedad, México: Universidad de Guadalajara, n. 14, julio-diciembre, 2010, p.169-198.

. El estudio de las emociones desde una perspectiva argumentativa. Anuario

de Investigación del Departamento de Educación y Comunicación, México: UAM Xochimilco, 2009, 2010b, p. 271-297.

. La emoción como motor en la movilización social. El caso Ayotzinapa,

En: Memorias del Congreso de la Asociación Mexicana de Investigadores de la Comunicación (AMIC), en prensa, 2017.

HOCHSCHILD, A. The Sociology of Feeling and Emotion: Selected Possibilities. En: MILLMAN, M.; KANTER, R. M. (Éds.) Another Voice. Feminist perspectives on social 
Life and Social Science. Nueva York: Anchor Books, 1975, p. 280-307.

KEMPER, T. A social interaction theory of emotions. Nueva York: Wiley, 1978.

. A structural approach to social movement emotions. En: GOODWIN, J.;

JASPER, M. J.; POLLETTA, F. Passionate Politics: Emotions and Social Movements.

Chicago: University of Chicago Press, 2001, p. 58-73.

LUTZ, A. C.; ABU-LUGHOD, L. "Introduction". En: Language and the politics of emotion. Cambridge Mass: Cambridge University Press, 1990, p. 1-23.

NUSSBAUM, M. El ocultamiento de lo humano. Repugnancia, vergüenza y ley.

Buenos Aires: Katz, 2006.

PLANTIN, C. Les raisons des émotions. En : BONDI, M. (Ed.) Forms of argumentative discourse / Per un'analisi linguistica dell'argomentare. Bolonia:

CLUEB, 1998, p. 3-50.

. Las buenas razones de las emociones. Buenos Aires: Universidad Nacional de Moreno, [2010] 2014.

. Lo que la lengua cuenta de sus emociones. ICAR, Universidad Lyon 2, 2016.

Disponible en: <http://www.icar.cnrs.fr/membre/cplantin/lo-que-la-lengua-cuenta-desus-emociones/>. Fecha consulta: 5 marzo 2017.

PLANTIN, C.; GUTIÉRREZ, S. La construcción política del miedo. En:

BENTIVOGLIO, P.; ERLICH, F. D.; SHIRO, M. (comps.). Haciendo discurso.

Homenaje a Adriana Bolívar. Caracas: Comisión de Estudios de Postgrado, Facultad de Humanidades y Educación, Universidad Central de Venezuela, 2009, p. 491-509.

PUIG, L. Del pathos clásico al efecto patémico en el análisis del discurso. Acta Poética, v. 29, n. 2, 2008, p. 393-413.

SALGADO, E. La prensa escrita en México frente al cambio de régimen. Revista

Mexicana de Ciencias Políticas y Sociales, n. 199, 2007, p. 35-62.

UNGERER, F. Emotions and emotional language in English and German news stories,

En: NIEMEIER, S.; DIRVEN, R. (Eds.). The Language of Emotions. Amsterdam: John Benjamin, 1997, pp. 307-328.

VAN DIJK, T. La noticia como discurso. Compresión, estructura y producción de la información. Barcelona: Paidós, 1990.

VARGAS, E. Medios de comunicación y emociones. El caso Ayotzinapa en dos diarios nacionales. Tesis de maestría en Comunicación y Política. México: UAM, Xochimilco, 2017.

VASILACHIS, I. Discurso político y prensa escrita. Argentina: Gedisa, 2009.

VERÓN, E. Ideología y comunicación de masas: La semantización de la violencia política En: VERÓN, E. et al. Lenguaje y comunicación social. Buenos Aires: Nueva Visión, 1971, p. 133-191.

VIRILIO, Paul. Ciudad Pánico: el afuera comienza aquí. Buenos Aires: Libros del Zorzal.

WALTON, Douglas (1992). The place of emotions in argument. University Park: The Pennsylvania State University Press, 2007.

WALTON, D. The place of emotions in argument. [S.1.]: Pennsylvania State University Press, (1992) 2007.

ZASLAVSKY, D. La prensa entre mediación y intermediación: el tercero como condición del discurso periodístico. En: MONTES, R.; CHARAUDEAU, P. (Coord.) El “tercero". Fondo y Figura de las personas en el discurso. México: Benemérita Universidad Autónoma de Puebla, 2009, p. 103-118. 


\section{Conexão Letras}

ZEPEDA, Jorge. "La prensa en México o la victima soberbia”. Cuadernos de

Periodistas, No. 2, 2005. Revista española de la Asociación de Prensa de Madrid.

Recuperado el 28 de junio de 2008 de http://www.jorgezepeda.net/01-09-2006/laprensa-en-mexico-o-lavictimasoberbia/

Recebido em: 05/09/2017 Aceito em: 11/10/2017 